\title{
Characterization of attaching and effacing Escherichia coli (AEEC) isolated from pigs and sheep
}

\author{
Erik Fröhlicher ${ }^{1}$, Gladys Krause ${ }^{2}$, Claudio Zweifel ${ }^{1}$, Lothar Beutin ${ }^{2}$ and \\ Roger Stephan*1
}

Address: ${ }^{1}$ Institute for Food Safety and Hygiene, Vetsuisse Faculty University of Zurich, Winterthurerstrasse 272, 8057 Zurich, Switzerland and ${ }^{2}$ National Reference Laboratory for Escherichia coli, Centre for Infectiology and Pathogen Characterization, Federal Institute for Risk Assessment, Berlin, Germany

Email: Erik Fröhlicher - ils@fsafety.uzh.ch; Gladys Krause - Gladys.Krause@bfr.bund.de; Claudio Zweifel - zweifelc@fsafety.uzh.ch; Lothar Beutin - Lothar.Beutin@bfr.bund.de; Roger Stephan* - stephanr@fsafety.unizh.ch

* Corresponding author

Published: II September 2008

BMC Microbiology 2008, 8:144 doi:10.1 I86/147|-2180-8-144
Received: 9 June 2008

Accepted: II September 2008

This article is available from: http://www.biomedcentral.com//47|-2/80/8//44

(c) 2008 Fröhlicher et al; licensee BioMed Central Ltd.

This is an Open Access article distributed under the terms of the Creative Commons Attribution License (http://creativecommons.org/licenses/by/2.0), which permits unrestricted use, distribution, and reproduction in any medium, provided the original work is properly cited.

\begin{abstract}
Background: Attaching and effacing Escherichia coli (AEEC) are characterized by their ability to cause attaching-and-effacing (A/E) lesions in the gut mucosa of human and animal hosts leading to diarrhoea. The genetic determinants for the production of $A / E$ lesions are located on the locus of enterocyte effacement (LEE), a pathogenicity island that also contains the genes encoding intimin (eae). This study reports data on the occurrence of eae positive $E$. coli carried by healthy pigs and sheep at the point of slaughter, and on serotypes, intimin variants, and further virulence factors of isolated AEEC strains.

Results: Faecal samples from 198 finished pigs and 279 sheep were examined at slaughter. The proportion of eae positive samples was $89 \%$ for pigs and $55 \%$ for sheep. By colony dot-blot hybridization, AEEC were isolated from 50 and 53 randomly selected porcine and ovine samples and further characterized. Strains of the serotypes $\mathrm{O} 2 \mathrm{H} 40, \mathrm{O} 3: \mathrm{H} 8$ and $\mathrm{O} 26: \mathrm{HII}$ were found in both pigs and sheep. In pigs O2:H40, O2:H49, OI08: $\mathrm{H} 9, \mathrm{OI} 45: \mathrm{H} 28$ and in sheep O2:H40, O26: $\mathrm{HII}, \mathrm{O} 70: \mathrm{H} 40, \mathrm{OI} 46: \mathrm{H} 2 \mathrm{I}$ were the most prevalent serotypes among typable strains. Eleven different intimin types were detected, whereas $\gamma 2 / \theta$ was the most frequent, followed by $\beta I, \varepsilon$ and $\gamma \mathrm{l}$. All but two ovine strains tested negative for the genes encoding Shiga toxins. All strains tested negative for the bfpA gene and the EAF plasmid. EASTI (astA) was present in 18 of the isolated strains.

Conclusion: Our data show that pigs and sheep are a source of serologically and genetically diverse intimin-harbouring $E$. coli strains. Most of the strains show characteristics of atypical enteropathogenic $E$. coli. Nevertheless, there are stx-negative AEEC strains belonging to serotypes and intimin types that are associated with classical enterohaemorrhagic $E$. coli strains $(\mathrm{O} 26: \mathrm{HII}, \beta \mathrm{I}$; $\mathrm{O} \mid 45: \mathrm{H} 28, \gamma \mathrm{I})$.
\end{abstract}




\section{Background}

Attaching and effacing Escherichia coli (AEEC) are characterized by their ability to cause attaching-and-effacing (A/ E) lesions in the gut mucosa of human and animal hosts leading to diarrhoea. The main mechanism of AEEC pathogenesis is the destruction of the gastric microvillus brush border through restructuring of the underlying cytoskeleton by signal transduction between bacterial and host cells, intimate adherence of strains to the intestinal epithelium, pedestal formation and aggregation of polymerized actin at the sites of bacterial attachment $[1,2]$. The adherence of bacteria to the enterocytes is mediated by intimin, an outer membrane protein encoded by the eae (E. coli attachment effacement) gene [2].

Intimin genes are present in enteropathogenic E. coli (EPEC) and some Shigatoxin-producing E. coli (STEC). EPEC strains are defined as eae harbouring diarrhoeagenic E. coli that possess the ability to form A/E lesions on intestinal cells and that do not possess Shigatoxin encoding genes [3]. According to their virulence markers, EPEC strains are subdivided into typical and atypical EPEC. Typical EPEC harbour the EAF (EPEC adherence factor) plasmid, which carries genes for regulation of LEE functions and for production of bundle-forming pili (BFP), which interconnect bacteria within microcolonies and lead to a characteristic localized adherence pattern. Atypical EPEC strains are negative for both, the EAF plasmid and BFP and show diffuse, aggregative or localized-like adherence patterns $[2,4]$. Moreover, typical and atypical EPEC usually belong to certain serotype cluster and differ in their geographic distribution and their natural reservoir. Typical EPEC are still a major cause of infantile diarrhoea in developing countries and are rarely found in animals. Atypical EPEC strains predominate in industrialized countries and can be isolated from both humans and animals [4]. Atypical EPEC appear to be more closely related to STEC and as such are considered emerging pathogens $[1,4,5]$. Their role in human infections is probably underestimated.

The second group of AEEC is formed by STEC strains, which produce Shigatoxins. STEC are responsible for a number of human gastrointestinal diseases, including diarrhoea and hemorrhagic colitis (HC). In a proportion of individuals, particularly in children, these conditions may be complicated by neurological and renal sequelae, including haemolytic-uremic syndrome (HUS) [6].

Although a number of studies have looked for the eae gene in STEC strains isolated from sheep and pigs, only a limited number of studies have been undertaken to screen pigs and sheep for AEEC and to further characterize such strains [7-9].
The aim of this study was to isolate eae positive E. coli strains carried by healthy pigs and sheep at slaughterhouse level and to provide further characterization data for such strains.

\section{Results}

A total of 198 faecal samples from pigs and 279 faecal samples from sheep collected at slaughter were tested for the presence of eae positive E. coli. AEEC were shed by 176 $(89 \%)$ and $154(55 \%)$ of pigs and sheep, respectively. Using colony dot-blot hybridization, 50 porcine and 53 ovine AEEC strains were identified and isolated.

Twenty-seven of the 50 eae positive porcine E. coli strains were typeable with $\mathrm{O}$ antisera (Table 1 ). They belonged to ten $\mathrm{O}$ serogroups, whereas 17 strains were of three serogroups, namely O2 (10 strains), O145 (4 strains) and O108 (3 strains). Eighteen strains were not typeable for

Table I: Characteristics of 50 attaching and effacing Escherichia coli isolated from pigs at slaughter $(n=50)$

\begin{tabular}{|c|c|c|c|c|c|}
\hline Serotype & No. of strains & eae type & ast $\mathrm{A}$ & tir genotype & stx \\
\hline $\mathrm{O} 2: \mathrm{H} 8$ & 1 & $\gamma 2 / \theta$ & - & Y-P & - \\
\hline $\mathrm{O} 2: \mathrm{H} 40$ & 3 & $\gamma 2 / \theta$ & - & $Y-P$ & - \\
\hline $\mathrm{O} 2: \mathrm{H} 49$ & 4 & 1 & - & Y-P & - \\
\hline O2:HNT & I & $\gamma 2 / \theta$ & - & Y-P & - \\
\hline O2:HNT & 1 & $\gamma 2 / \theta$ & - & Y-P & - \\
\hline O3:H8 & I & $\gamma 2 / \theta$ & - & Y-P & - \\
\hline O26:HII & 2 & $\varepsilon$ & - & Y-P & - \\
\hline O45:HII & I & $\beta I$ & - & Y-P & - \\
\hline O88:H25 & 1 & $\eta$ & - & Y-P & - \\
\hline O88:H25 & I & $\zeta$ & - & Y-P & - \\
\hline O108:H9 & 3 & $\beta I$ & - & Y-P & - \\
\hline OI2I:H45 & I & $\gamma 2 / \theta$ & - & Y-P & - \\
\hline $\mathrm{O} 145: \mathrm{H} 28$ & 4 & $\gamma I$ & - & $S$ & - \\
\hline OI53:HIO & 1 & $\kappa$ & - & $Y-P$ & - \\
\hline OI53:HNT & 1 & $\kappa$ & + & Y-P & - \\
\hline O180:H2 & I & $\varepsilon$ & - & untypable & - \\
\hline ONT:H2 & 2 & $\beta I$ & - & Y-P & - \\
\hline ONT:H2 & 3 & $\varepsilon$ & - & Y-P & - \\
\hline ONT:H5 & 2 & $\kappa$ & - & Y-P & - \\
\hline ONT:H6 & 1 & $\alpha 2$ & + & $S$ & - \\
\hline ONT:H6 & I & $\gamma 2 / \theta$ & - & Y-P & - \\
\hline ONT:H7 & 4 & $\gamma 2 / \theta$ & - & Y-P & - \\
\hline ONT:HIO & 2 & $\kappa$ & + & Y-P & - \\
\hline ONT:HII & 1 & $\beta I$ & - & Y-P & - \\
\hline ONT:H40 & I & $\gamma 2 / \theta$ & - & $Y-P$ & - \\
\hline ONT:H49 & I & $\mathrm{i}$ & - & Y-P & - \\
\hline Orough:HII & 1 & $\beta I$ & - & Y-P & - \\
\hline Orough:H28 & 2 & $\gamma I$ & - & $S$ & - \\
\hline Orough:H40 & 1 & $\gamma 2 / \theta$ & - & Y-P & - \\
\hline Orough:HNT & I & $\gamma l$ & - & $S$ & - \\
\hline
\end{tabular}

Y-P: EPEC-type translocated intimin receptor $S$ : STEC-type translocated intimin receptor eae: gene encoding intimin astA: gene encoding EASTI tir: gene encoding translocated intimin receptor stx: gene encoding Shigatoxin 
the O-antigen (ONT) and five had a rough Lipopolysaccharide (LPS type, spontaneously agglutinating). Strains of the serogroup $\mathrm{O} 2$ showed different $\mathrm{H}$ types and the two strains of serotype O88:H25 carried two different intimin variants $(\eta$ and $\zeta$ ). Thirty-six of the 53 eae positive ovine E. coli strains were typeable with $\mathrm{O}$ antisera (Table 2). They belonged to $15 \mathrm{O}$ serogroups, whereas 17 strains were of three serogroups, namely O146 (9 strains), O2 (4 strains) and O70 (4 strains). Sixteen strains were ONT and one had a rough LPS type. Strains of the serogroup O70 and $\mathrm{O} 116$ showed different $\mathrm{H}$ types. Overall, only five O26:H11 strains (two porcine and three ovine strains) belonged to a known human EPEC serotype. Besides, this serotype (O26:H11) has also been reported in association

Table 2: Characteristics of 53 attaching and effacing Escherichia coli isolated from sheep at slaughter $(n=53)$

\begin{tabular}{|c|c|c|c|c|c|}
\hline serotype & No. of strains & eae type & ast $\mathrm{A}$ & tir genotype & stx \\
\hline $\mathrm{O} 2: \mathrm{H} 40$ & 3 & $\gamma 2 / \theta$ & - & Y-P & - \\
\hline $\mathrm{O} 2: \mathrm{H} 40$ & I & $\gamma 2 / \theta$ & + & Y-P & - \\
\hline O3:H8 & I & $\gamma 2 / \theta$ & - & Y-P & - \\
\hline O26:HII & 3 & $\beta 1$ & - & Y-P & - \\
\hline $\mathrm{O} 35: \mathrm{H} 2$ & 1 & $\beta 1$ & - & Y-P & - \\
\hline O5I:H49 & I & $\alpha 1$ & - & Y-P & - \\
\hline O70:HII & I & $\beta I$ & - & Y-P & - \\
\hline O70:H40 & 3 & $\gamma 2 / \theta$ & + & Y-P & - \\
\hline O7I:HII & I & $\beta 1$ & - & Y-P & - \\
\hline O96:H7 & I & $\beta 2 / \delta$ & - & Y-P & - \\
\hline O103:H25 & I & $\gamma 2 / \theta$ & - & Y-P & - \\
\hline Oll6:H5 & I & $\beta 1$ & - & $Y-P$ & - \\
\hline $\mathrm{Ol} 16: \mathrm{H} 20$ & 2 & $\beta 1$ & - & Y-P & - \\
\hline OI2I:HI9 & 2 & $\varepsilon$ & - & Y-P & + \\
\hline Ol45:H34 & 1 & 1 & - & Y-P & - \\
\hline OI45:HNT & I & $\gamma l$ & - & S & - \\
\hline $\mathrm{O} 146: \mathrm{H} 2 \mathrm{I}$ & 5 & $\gamma 2 / \theta$ & + & Y-P & - \\
\hline $\mathrm{O} 146: \mathrm{H} 2 \mathrm{I}$ & 4 & $\gamma 2 / \theta$ & - & Y-P & - \\
\hline OI56:HNT & 1 & $\zeta$ & - & Y-P & - \\
\hline OI56:HNT & I & $\gamma 2 / \theta$ & - & $Y-P$ & - \\
\hline O16I:HNT & 1 & $\varepsilon$ & - & Y-P & - \\
\hline ONT:H2 & 2 & $\beta I$ & - & Y-P & - \\
\hline ONT:H6 & I & $\alpha l$ & - & $Y-P$ & - \\
\hline ONT:H6 & I & $\beta 2 / \delta$ & + & Y-P & - \\
\hline ONT:H6 & 2 & $\beta 2 / \delta$ & - & Y-P & - \\
\hline ONT:H6 & I & untypable & - & $S$ & - \\
\hline ONT:H9 & 1 & $\beta 1$ & + & Y-P & - \\
\hline ONT:H3I & 1 & $\gamma 2 / \theta$ & - & Y-P & - \\
\hline ONT:H40 & 2 & $\gamma 2 / \theta$ & - & $Y-P$ & - \\
\hline ONT:HNT & 1 & $\gamma I$ & + & $S$ & - \\
\hline ONT:HNT & I & $\gamma 2 / \theta$ & - & Y-P & - \\
\hline ONT:HNT & I & $\kappa$ & + & Y-P & - \\
\hline ONT:HNT & I & $\beta I$ & - & Y-P & - \\
\hline ONT:HNT & I & $\varepsilon$ & - & Y-P & - \\
\hline Orough:H6 & I & $\beta 2 / \delta$ & + & Y-P & - \\
\hline
\end{tabular}

Y-P: EPEC-type translocated intimin receptor $S$ : STEC-type translocated intimin receptor eae: gene encoding intimin

astA: gene encoding EASTI

tir: gene encoding translocated intimin receptor

stx: gene encoding Shigatoxin with human enterohaemorrhagic E. coli (EHEC) strains causing severe disease.

In total, a variety of 11 different intimin types and subtypes were found. The 50 isolated porcine AEEC (Table 1) harboured 9 variants, and $\beta 1$ ( 8 strains), $\gamma 1$ (7 strains), $\varepsilon$ ( 6 strains), $\gamma 2 / \theta$ (15 strains), 1 (5 strains), $\kappa$ ( 6 strains) were the frequently found. The 53 isolated ovine eae positive E. coli strains (Table 2) harboured 9 different intimin variants, and $\beta 1$ (13 strains), $\beta 2 / \delta$ ( 5 strains), $\varepsilon$ (4 strains), $\gamma 2 / \theta$ (23 strains) were the most frequently found. One strain was not typeable. For this strain no PCR product was obtained with SK1 as the forward primer and all used reverse primers.

All but two ovine AEEC strains (O121:H19, intimin $\varepsilon$ ) tested negative for genes encoding Shigatoxins. All strains tested negative for $b f p A$ and the EAF plasmid. EAST1 (astA) was present in 18 strains, four porcine and 14 ovine strains. Forty-one porcine and 50 ovine strains tested positive for tir-Y-P (EPEC-type called Y-P). For one porcine strain there were no PCR products present in the tir specific PCRs. This strain was therefore not typable for this genotype. Remarkably, all strains encoding intimin $\gamma 1$ were associated with tir-S (STEC-type called S).

\section{Discussion}

The high percentages of animals shedding AEEC are remarkable, especially in view of frequencies of sheep and pigs colonized with AEEC found in these animal species in previous works [7-9]. Indeed, de la Fuente et al. [7] and Krause et al. [9] detected AEEC in less than $20 \%$ of the sheep and pigs studied, while in our work these percentages were $89 \%$ for pigs and $55 \%$ for sheep. Aktan et al. [8] found $17.7 \%$ and $0.75 \%$ AEEC strains from sheep and pigs, respectively.

In our study, no strains showing characteristics of typical EPEC were found. These results are consistent with earlier reports that most AEEC strains from sheep and pigs are negative for $s t x$ genes and $b f p \mathrm{~A}$, and are therefore considered as atypical EPEC $[8,9]$.

Pigs and sheep are reservoirs of serologically and genetically diverse intimin harbouring E. coli. In our study, only strains of the serotypes $\mathrm{O} 2: \mathrm{H} 40, \mathrm{O} 3: \mathrm{H} 8$ and O26:H11 were commonly isolated from both pigs and sheep. All other serotypes were different. This could indicate that atypical EPEC are adapted to their particular animal host. In pigs, serogroups $\mathrm{O} 2, \mathrm{O} 108$ and $\mathrm{O} 145$ and serotypes O2:H40, O2:H49, O108:H9, O145:H28 were most frequently found. Intimin types showed a wide diversity with $\theta, \beta 1$ and $\gamma 1$ as the most frequent types. These results partly agree with other studies performed on healthy pigs in Germany and Hungary $[9,10]$, considering that the lat- 
ter study was performed on weaned pigs. Our results show more intimin types and slightly different serotype patterns with more untypeable $\mathrm{O}$ serogroups and $\mathrm{O} 2$ as the most frequent one. In sheep, serogroups $\mathrm{O} 2, \mathrm{O} 26$; $\mathrm{O} 70$ and O146 and serotypes O2:H40, O26:H11, O70:H40, $\mathrm{O} 146: \mathrm{H} 21$ were most frequently found. Intimin types showed a wide diversity with $\gamma 2 / \theta$ and $\beta 1$ as the most frequent types. Compared to studies performed on healthy sheep in England, Wales, and Australia [8,11], the ovine strains isolated in Switzerland harboured more frequently the intimin $\gamma 2 / \theta$ type. But a high prevalence $(37.5 \%)$ of this intimin type in healthy sheep was also shown in a Spanish study [12].

Ovine isolates reported in the literature show more genetic similarity to bovine than porcine strains. Namely $\mathrm{O} 2, \mathrm{O} 26, \mathrm{O} 35, \mathrm{O} 70, \mathrm{O} 103, \mathrm{O} 145$ and $\mathrm{O} 156$ were found in studies on healthy cattle in Germany, England and Wales, Spain, Switzerland and Brazil $[8,9,12-14]$. Apart from intimin $\gamma 2 / \theta$, which was found much more often in ovine strains than bovine, the distribution of intimin types is rather similar in the present study.

The only classical human EPEC serotype found in our study was O26:H11 (2 pig strains, 3 ovine strains), indicating that classical EPEC serotypes might not be very common in these animal species. Moreover, no serotypes known for causing large outbreaks such as $\mathrm{O} 39: \mathrm{H}-$, O88:H55, O91:H7 and O111:H9 were found. However, $17 \%$ of all strains carried EAST1. The percentage (26.4\%) of ovine AEEC strains that harboured this gene was similar to that found by Aktan et al. [8], but much higher than that found by Yuste et al. [15]. Even the significance of this low-molecular-weight, plasmid-mediated, heat-stable enterotoxin in AEEC pathogenesis is still unknown, large EPEC outbreaks in adults have been associated with EAST1 positive strains and recent studies found EAST1 to be associated significantly with diarrhoea [16-18].

Hence most of the strains showed characteristics of atypical EPEC. Nevertheless, there are seven stx negative AEEC strains belonging to serotypes and eae types that are associated with typical EHEC strains (O26:H11, $\beta 1$; $\mathrm{O} 145: \mathrm{H} 28, \gamma 1)$. The reason that these strains are stx negative might be due to the fact that STEC strains can undergo ephemeral interconversions via loss and gain of Stxencoding phages, which leads to different pathotypes. This was already shown for $E$. coli $\mathrm{O} 157$ of the $\mathrm{H} 7$ clone $[19,20]$ and for E. coli O26 [21]. Ongoing studies in our laboratories aim to further characterize the $\mathrm{O} 26$ and O145 strains in view of phage integration sites as well as to perform transduction experiments on these strains.

\section{Conclusion}

Our data show that pigs and sheep are a source of serologically and genetically diverse intimin harbouring E. coli strains. Most of the strains show characteristics of atypical EPEC. Nevertheless, there are stx negative AEEC belonging to serotypes and intimin types that are associated with typical EHEC strains (O26:H11, $\beta 1 ; \mathrm{O} 145: \mathrm{H} 28, \gamma 1)$.

\section{Methods \\ Strains}

Samples examined in this study were collected within nine months (from March to November 2007) in an EUapproved slaughterhouse in Switzerland. In total, fecal samples of 198 healthy finished pigs and 279 healthy adult sheep randomly distributed over Switzerland were collected during 10 and 11 sampling days, respectively. Samples were subsequently placed into cool boxes. Microbiological examination was carried out within 1 to $3 \mathrm{~h}$ after sampling. Upon arrival in the laboratory, $10 \mathrm{~g}$ of each sample were enriched in $100 \mathrm{ml}$ of brilliant green bile broth (BBL, Cockeysville, Md.) at $37^{\circ} \mathrm{C}$ for $24 \mathrm{~h}$.

The enriched samples were streaken onto sheep blood agar (Difco Laboratories, Detroit, Mich.; 5\% sheep blood Oxoid, Hampshire, UK), and after incubation at $37^{\circ} \mathrm{C}$ for another $24 \mathrm{~h}$, the colonies were washed off with $2 \mathrm{ml}$ of $0.85 \%$ saline solution. Of each plate eluate $2.0 \mu \mathrm{l}$ were then evaluated by PCR with primers SK1 and SK2 amplifiying a $863-\mathrm{kb}$ product targeting sequences at the $5^{\prime}$ eae conserved region detecting all types of eae described at the moment [22]. From the eae PCR-positive samples, 50 porcine and 53 ovine samples were randomly selected for strain isolation with an eae DNA probe and colony dotblot hybridization. The eae probes were prepared by labelling eae-PCR amplicons from E. coli O157:H7 strain 857/ 03 with DIG High Prime kit (Roche, Mannheim, Germany). For colony hybridization, the eae positive samples were plated onto sheep blood agar and incubated overnight at $37^{\circ} \mathrm{C}$. Colonies were transferred to a nylon membrane (Roche), and lysed following standard methods. After washing, crosslinking, and prehybridization in DIGEasy-Hyb buffer (Roche) at $42{ }^{\circ} \mathrm{C}$ for about $60 \mathrm{~min}$, hybridization of membranes with eae DNA probes was performed overnight at $42^{\circ} \mathrm{C}$. After washing in primary and secondary wash buffers, the presence of labelled probe was detected with an alkaline phosphatase-conjugated antibody detection kit and NBT/BCIP stock solution according to the instructions of the manufacturer (Roche). Positive colonies were picked from the original sheep blood agar and confirmed to be eae positive by PCR. One randomly chosen colony per sample was used for further strain characterization.

\section{Strain characterization}

Determination of $\mathrm{O}$ antigens was performed as described [23] by tube agglutination tests with boiled cultures of bacteria using monospecific O-antisera (O1 to O185) at the National Reference Laboratory for Escherichia coli (NRL-E. coli). Determination of H-types was performed 
Table 3: PCR primers used for the identification and characterization of attaching and effacing Escherichia coli strains

\begin{tabular}{|c|c|c|c|}
\hline Target & Primer & Oligonucleotide sequence $\left(5^{\prime}-3^{\prime}\right)$ & Reference \\
\hline \multirow[t]{2}{*}{ ast $A$} & Eastl la & CCA TCA ACA CAG TAT ATC CGA & 27 \\
\hline & East I Ib & GGT CGC GAG TGA CGG CTT TGT & \\
\hline \multirow[t]{2}{*}{$b f p A$} & EPI & AAT GGT GCT TGC GCT TGC TGC & 5 \\
\hline & EP2 & GCC GCT TTA TCC AAC CTG GTA & \\
\hline \multirow[t]{2}{*}{ eae } & SKI & CCC GAA TTC GGC ACA AGC ATA AGC & 22 \\
\hline & SK2 & CCC GGA TCC GTC TCG CCA GTA TTC G & \\
\hline eae- $\alpha$ & SKI-LP2 & CCC GAA TTC TTA TTT TAC ACA AGT GGC & 25 \\
\hline eae- $\gamma$ & SKI-LP3 & CCC GAA TTC TTC TTT TAC ACA AAC CGC & 25 \\
\hline eae- $\beta$ & SKI-LP4 & CCC GTG ATA CCA GTA CCA ATT ACG GTC & 22 \\
\hline eae- $\varepsilon$ & SKI-LP5 & AGC TCA CTC GTA GAT GAC GGC AAG CG & 22 \\
\hline eae- $\zeta$ & SKI-LP6B & TAG TTG TAC TCC CCT TAT CCC & 25 \\
\hline eae-1 & SKI-LP7 & TTT ATC CTG CTC CGT TTG CT & 25 \\
\hline eae- $\eta$ & SKI-LP8 & TAG ATG ACG GTA GAC & 25 \\
\hline eae- $\kappa$ & SKI-LPIO & GGC ATT GTT ATC TGT TGT CT & 25 \\
\hline eae- $\theta$ & SKI-LPIIB & GTT GAT AAC TCC TGA TAT TTT A & 25 \\
\hline \multirow[t]{2}{*}{ EAF } & EAFI & CAG GGT AAA AGA AAG ATG ATA A & 27 \\
\hline & EAF25 & TAT GGG GAC CAT GTA TTA TCA & \\
\hline \multirow[t]{2}{*}{ flic } & FliC up & CAA GTC ATT ATT AC(AC) AAC AGC C & 5 \\
\hline & FliC down & GAC AT(AG) TT(AG)GA(AGC) ACT TC(GC) GT & \\
\hline \multirow[t]{2}{*}{ stx } & VTI & ATT GAG CAA AAT AAT TTA TAT GTG & 27 \\
\hline & VT2 & TGA TGA TGG CAA TTC AGT AT & \\
\hline tir & tir-R & TAA AAG TTC AGA TCT TGA CAT & 26 \\
\hline $\operatorname{tir} \mathrm{Y}-\mathrm{P}$ & $\operatorname{tir} Y 474-\mathrm{F}$ & CAT ATT TAT GAT GAG GTC GCT C & \\
\hline $\operatorname{tir} \mathrm{S}$ & tisS478-F & TCT GTT CAG AAT ATG GGG AAT A & \\
\hline
\end{tabular}

astA: gene encoding EASTI

bfPA: gene encoding bundle-forming pili

eae: gene encoding intimin

flic: gene encoding flagellum

EAF: EPEC adherence factor

tir: gene encoding translocated intimin receptor

stx: gene encoding Shigatoxin

with H-specific antisera prepared at the NRL-E. coli (BfR) and flagellar $(f l i C)$ genotypes of nonmotile strains were identified by PCR followed by digestion of PCR products with $H$ haI resulting in $f l i C$-genotype-specific profiles as described previously [24].

Subtyping of intimin genes was performed using primer SK1 in combination with intimin-type specific reverse primers $[22,25]$. Genetic subtyping of eae genes encoding intimins $\alpha, \beta$ and $\gamma$ was done by restriction fragment length polymorphism (RFLP)-analysis of PstI digested PCR products as described [22]. For detection of further putative virulence genes, strains were examined for the presence of $s t x$ genes, the EAF plasmid, the $b f p$ A gene, and the ast $\mathrm{A}$ gene encoding EAST1 (Table 3). To distinguish between phosphorylated $\operatorname{tir}_{\mathrm{E} 2348 / 68}$ (EPEC-type called Y-P) and nonphosphorylated $t i r_{\text {Sakai }}$ (STEC-type called S), gene specific forward primers (tirY474-F: 5'-CATATTTATGATGAGGTCGCTC-3' and tirS478-F: 5'-TCTGTTCAGAATATGGGGAATA-3') were used together with a conserved reverse primer (tirR: 5'-TAAAAGTTCAGATCTTGATGACAT-3') [26]. In order to improve the results in this PCR $\left(5 \min 94^{\circ} \mathrm{C} ; 34 \times 30 \sec 94^{\circ} \mathrm{C}, 30 \sec 50^{\circ} \mathrm{C}, 30 \sec 72^{\circ} \mathrm{C}\right.$; $\left.5 \min 72^{\circ} \mathrm{C}\right), \mathrm{MgCl} 2$ was added to a final $\mathrm{Mg}^{2+}$ concentration of $5 \mathrm{mM}$. All PCR reactions were run with a negative and a positive control strain.

\section{Authors' contributions}

RS and CZ designed the study and drafted the manuscript. $\mathrm{EF}$ isolated the strains and was responsible for further strain characterisation, GK and LB performed serotyping of the strains and the PCR typing of eae genes. All authors read, commented on and approved of the final manuscript.

\section{Acknowledgements}

The authors thank the staff of the slaughterhouse for facilitating access to their operations and for the assistance with the collection of data.

\section{References}

I. Frankel G, Phillips AD, Rosenshine I, Dougan G, Kaper JB, Knutton S: Enteropathogenic and enterohemorrhagic Escherichia coli: more subversive elements. Mol Microbiol 1998, 30:91 I-921.

2. Nataro JP, Kaper JB: Diarrheagenic Escherichia coli. Clin Microbiol Rev 1998, II:| 142-201.

3. Kaper JB: Defining EPEC. Rev Microbiol 1996, 27:130-133.

4. Trabulsi LR, Keller R, Tardelli Gomes TA: Typical and atypical enteropathogenic Escherichia coli. Emerg Infect Dis 2002, 8:508-513. 
5. Beutin L, Marchés O, Bettelheim KA, Gleier K, Zimmermann S, Schmidt $H$, Oswald E: HEp-2 cell adherence, actin aggregation, and intimin types of attaching and effacing Escherichia coli strains isolated from healthy infants in Germany and Australia. Infect Immun 2003, 7 I:3995-4002.

6. Paton JC, Paton AW: Pathogenesis and diagnosis of Shiga toxinproducing $\boldsymbol{E}$. coli infections. Clin Microbiol Rev 1998, I I:450-479.

7. De la Fuente R, Garcia S, Orden JA, Ruiz-Santa-Quiteria JA, Diez R, Did D: Prevalence and characteristics of attaching and effacing strains of $E$. coli isolated from diarrheic and healthy sheep and goats. Am J Vet Res 2002, 63:262-266.

8. Aktan I, Sprigings KA, La Ragione RM, Faulkner LM, Paiba GA, Woodward MJ: Characterization of attaching-effacing Escherichia coli isolated from animals at slaughter in England and Wales. Vet Microbiol 2004, 1 02:43-53.

9. Krause G, Zimmermann S, Beutin L: Investigation of domestic animals and pets as a reservoir for intimin- (eae) gene positive Escherichia coli types. Vet Microbiol 2005, I 06:87-95.

10. Malik A, Istvan T, Beutin L, Schmidt H, Taminiau B, Dow MA, Morabito S, Oswald E, Mainil J, Nagy B: Serotypes and intimin types of intestinal and faecal strains of eae ${ }^{+}$Eschericha coli from weaned pigs. Vet Microbiol 2006, I I 4:82-93.

II. Ramachandran V, Brett K, Hornitzky MA, Dowton M, Beltelheim KA, Walker MJ, Djordjevic SP: Distribution of intimin subtypes among Eschericha coli isolates from ruminant and human sources. J Clin Microbiol 2003, 4I:5022-5032.

12. Orden JA, Yuste M, Cid D, Piacesi T, Martinez S, Ruiz-Santa-Quiteria JA, De la Fuente R: Typing of the eae and espB genes of attaching and effacing Escherichia coli isolates from ruminants. Vet Microbiol 2003, 96:203-215.

13. Blanco M, Schumacher S, Tasara T, Zweifel C, Blanco JE, Ghizlane D, Blanco J, Stephan R: Serotypes, intimin variants and other virulence factors of eae positive Escherichia coli strains isolated from healthy cattle in Switzerland. Identification of a new intimin variant gene (eae-eta2). BMC Microbiol 2005, 5:23.

14. Aidar-Ugrinovich L, Blanco J, Blanco M, Blanco JE, Leomil L, Dahbi G, Mora A, Onuma DL, Silveira WD, Pestana de Castro AF: Serotypes, virulence genes, and intimin types of Shiga toxin-producing Escherichia coli (STEC) and enterpathogenic E. coli (EPEC) isolated from calves in Sao Paulo, Brazil. Int J Food Mirobiol 2007, I I 5:297-306.

15. Yuste M, de la Fuente R, Ruiz-Santa-Quiteria JA, Cid D, Orden JAJ, Beutin L: Detection of the ast $A$ (EASTI) gene in attaching and effacing $E$. coli from ruminants. J Vet Med B 2006, 53:75-77.

16. Zamboni A, Fabbricotti SH, Fagundes-Neto U, Scaletsky IC: Enteroaggregative Escherichia coli virulence factors are found to be associated with infantile diarrhea in Brazil. J Clin Microbiol 2004, 42:1058-1063.

17. Zhang W, Berberov EM, Freeling J, He D, Moxley RA, Francis DH: Significance of heat-stable and heat-labile enterotoxins in porcine colibacillosis in an additive model for pathogenicity studies. Infect Immun 2006, 74:3107-3II4.

18. Jensen C, Ethelberg S, Olesen B, Schiellerup P, Olsen KE, Scheutz F, Nielsen EM, Neimann J, Hogh B, Gerner-Smidt P, Molbak K, Krogfelt A: Attaching and effacing Escherichia coli isolates from Danish children: clinical significance and microbiological characteristics. Clin Microbiol Infect 2007, I 3:863-872.

19. Friedrich AW, Zhang W, Bielaszewska M, Mellmann A, Köck R, Furth $A$, Tschäpe $H$, Karch $H$ : Prevalence, virulence profiles, and clinical significance of Shiga toxin-negative variants of enterohemorrhagic E. coli OI 57 infection in humans. Clin Infect Dis 2007, 45:39-45.

20. Mellmann A, Lu S, Karch H, Xu J, Harmsen D, Schmidt MA, Bielaszewska M: Recycling of Shiga toxin 2 genes in sorbitol-fermenting enterohemorrhagic E. coli O I57:NM. Appl Environ Microbiol 2008, 74:67-72.

21. Bielaszewska M, Prager R, Köck R, Mellman A, Zhang W, Tschäpe H, Tarr PI, Karch H: Shiga Toxin gene loss and transfer in vitro and in vivo during enterohemorrhagic Escherichia coli 026 infection in humans. Appl Environ Microbiol 2007, 73:3 I44-3I 50.

22. Oswald E, Schmidt H, Morabito S, Karch H, Marche O, Caprioli A: Typing of intimin genes in human and animal enterohemorrhagic and enteropathogenic Escherichia coli: characterization of a new intimin variant. Infect Immun 2000, 68:64-7I.

23. Orskov F, Orskov I: Serotyping of Escherichia coli. Methods Microbiol 1984, I4:43-II2.
24. Beutin L, Krause G, Zimmermann S, Kaulfuss S, Gleier K: Characterization of Shiga toxin-producing Escherichia coli strains isolated from human patients in Germany over a 3-year period. J Clin Microbiol 2004, 42: I099-I 108.

25. Zhang WL, Köhler B, Oswald E, Beutin L, Karch H, Morabito S, Caprioli A, Suerbaum S, Schmidt H: Genetic diversity of intimin genes of attaching and effacing Escherichia coli strains. J Clin Microbiol 2002, 40:4486-4492.

26. Ogura Y, Ooka T, Whale A, Garmendia J, Beutin L, Tennant S, Krause G, Morabito S: TccPM of O I57:H7 and non O 157 enterohemorrhagic Escherichia coli (EHEC): challenging the dogma of EHEC induced actin polymerization. Infect Immun 2007, 75:604-6I2

27. Kaufmann M, Zweifel C, Blanco M, Blanco JE, Blanco J, Beutin L, Stephan R: Escherichia coli OI57 and non-OI57 Shiga toxinproducing Escherichia coli in fecal samples of finished pigs at slaughter in Switzerland. J Food Prot 2006, 69:260-266.
Publish with Bio Med Central and every scientist can read your work free of charge

"BioMed Central will be the most significant development for disseminating the results of biomedical research in our lifetime. "

Sir Paul Nurse, Cancer Research UK

Your research papers will be:

- available free of charge to the entire biomedical community

- peer reviewed and published immediately upon acceptance

- cited in PubMed and archived on PubMed Central

- yours - you keep the copyright

Submit your manuscript here:

http://www.biomedcentral.com/info/publishing_adv.asp
BioMedcentral 